На грунті здійсненого у статті аналізу проблеми педагогічної технології формування вмінь моделювання у студентів вищих економічних навчальних закладів у процесі самостійної навчальної діяльності робимо висновки про необхідність упровадження технології в практику задля розвитку групи умінь моделювання (гностичні, проектувально-конструктивні, дослідницько-творчі, оцінно-рефлексивні) у студентів економічних спеціальностей. Установлені структурні частини цієї технології є ії системоутворювальними компонентами. Відповідно до структури педагогічної технології розроблено технологію, що передбачає формування груп умінь моделювання (гностичні, проектувально-конструктивні, дослідницькотворчі, оцінно-рефлексивні) і має три етапи: мотиваційно-пізнавальний; тренувальнодіяльнісний; рефлексивно-творчий. Для кожного етапу визначено мету, завдання, методи та форми організації навчальної діяльності студентів, засоби управління їхньою діяльністю.

Визначена й теоретично обгрунтована структура педагогічної технології може слугувати теоретичним підгрунтям для організації експериментальної роботи щодо оволодіння вказаними зазначеними вміннями. Подальші дослідження передбачається здійснити в напрямку поглибленого вивчення процесуальної частини педагогічної технології формування вмінь моделювання у студентів вищих економічних навчальних закладів у процесі самостійної навчальної діяльності.

1. Беспалько В. П. Слагаемые педагогической технологии / В. П. Беспалько. - М. : Педагогика, 1988. - 192 с. 2. Бутенко Т. О. Обгрунтування педагогічної технології формування комунікативної компетентності майбутніх інженерів [Електронний ресурс]/ Т. О. Бутенко // Режим доступу: http://www.nbuv.gov.ua/portal/soc_gum/pfto/2009_3/files/ped_2009_03_16_Butenko.pdf. 3. Гриньова М. В. Педагогічні технології: теорія та практика : [навч.-метод. посіб.] / за ред. проф. М. В. Гриньової. Полтава : ACMI, 2008. - 230 с. 4. Дичківська І. М. Інноваційні педагогічні технології / І. М. Дичківська. - К. : Академвидав, 2004. - 352 с. 5. Ковальчук Г. О. Формування професійних педагогічних умінь у студентів - майбутніх викладачів економіки : автореф. дис. на здобуття наук. ступеня канд. пед. наук: спец. 13.00.04 «Теорія і методика професійної освіти» / Г. О. Ковальчук. - К., 1999. - 18 с. 6. Кучер А. В. Структура педагогічної технології формування вмінь професійного спілкування [Електронний ресурс]// Режим доступу: http://archive.nbuv.gov.ua /portal/Soc_Gum /Vlush/Ped/2011_20_2/26.pdf. 7. Махмутов М. И. Педагогические технологи развития мышления / М. И. Махмутов, Г. И. Ибрагимов. - Казань, 1993. - 88 с. 8. Мойсеюк Н. Є. Педагогіка : [навч. посіб.] / Н. С. Мойсеюк. - [5-е вид.]. -К., 2007. - 656 с. 9. Основы педагогики высшей школы : [учеб. пособ.] / Л. Л. Товажнянский [и др.]. - Харьков : НТУ «ХПИ», 2005. - 600 с. 10. Прокопенко І. Ф. Педагогічні технології : [навч. посіб.] / І. Ф. Прокопенко, В. І. Євдокимов. - Х. : Колегіум, 2005. - 224 с. 11. Степанов О. М. Основи психології і педагогіки : [посібник] /О. М. Степанов, М. М. Фіцула. - К. : Академвидав, 2003. -504 с.

Оксана Цигуль

\title{
ОСОБЛИВОСТІ ФОРМУВАННЯ СКЛАДНИКІВ ІНШОМОВНОЇ КОМПЕТЕНТНОСТІ У СТУДЕНТІВ ІНЖЕНЕРНОЇ СПЕЦАЛЬНОСТІ
}

Цигуль О. В. Особливості формування складників іншомовної компетентності у студентів інженерної спеціальності.

У статті на основі аналізу наукової літератури визначаються та характеризуються структурні компоненти (комунікативний, соціолінгвістичний, прагматичний) іншомовної компетентності, окреслюються шляхи їх формування у студентів інженерної спеціальності.

Ключові слова: іншомовна компетентність, комунікативна компетенція, соціолінгвістична компетенція, прагматична компетенція.

Цыгуль О. В. Особенности формирования составляющих иноязычной компетентности у студентов инженерной специальности.

В статье на основе анализа научной литературы определяются и характеризуются структурные компоненты (коммуникативный, социолингвистический, прагматический) иноязычной компетентности, намечаются пути их формирования у студентов инженерной специальности.

Ключевые слова: иноязычная компетентность, коммуникативная компетенция, социолингвистическая компетенция, прагматическая компетенция. 
Tsygul O. V. The peculiarities of forming of foreign language competence components for students of engineering speciality.

The structural components (communicative, sociolinguistic, pragmatic) of foreign language competence based on the analysis of scientific literature are determined and described in the article. The ways of forming them for students of engineering speciality are outlined.

Key words: foreign language competence, communicative competence, sociolinguistic competence, pragmatic competence.

Підвищення якості підготовки спеціалістів із вищою технічною освітою, адекватної потребам сучасного виробництва, таких, що володіють необхідними професійно важливими якостями, знаннями та вміннями, здатні самостійно та швидко адаптуватися в безперервно мінливих інформаційному й технологічному середовищах, залежить від організації навчального процесу.

Металургійна професія є дуже важливою за ступенем впливу інженерної праці загалом на суспільство. ЮНЕСКО за участю міжнародних організацій FEANI (Свропа) й ABET (Америка), асоціацій інженерної освіти та спілок інженерів, розроблено вимоги до інженерів XXI ст., з-поміж яких виокремлюємо такі: висока професійна компетентність, прагнення до постійного особистісного та професійного вдосконалення й розвитку власного інтелектуального потенціалу, володіння методами моделювання, прогнозування, проектування, методами досліджень і випробувань, необхідних для створення нових інтелектуальних і матеріальних цінностей, володіння іноземною мовою, пов'язане 3 необхідністю засвоєння великої кількості сучасних світових інформаційних ресурсів тощо.

У цьому зв'язку іншомовна компетентність майбутнього інженера-металурга є невід'ємним компонентом його професійної компетентності, тому що дозволяє йому у професійній діяльності максимально адекватно актуалізувати власні інтелектуальні та креативні здібності, набуті спеціальні знання, вміння та навички як на рецептивному, так і на продуктивному рівнях, завдяки чому він зможе ознайомитися з новітніми досягненнями в професійній сфері.

У сучасній науковій літературі (В. Андрущенко, Є. Бачинська, Г. Вайлер, Ж. Делор, Я. Лефстед, А. Маркова, Дж. Мід, О. Овчарук, Н. Ничкало та інші) слушно вказується, що розвиток компетентного фахівця в будь-якій царині відбувається в процесі взаємодії з іншими людьми в суспільстві як системі безпосередніх комунікацій. Зазначимо також, що відповідно до Європейських рамкових програм й установок [5] однією з ключових компетенцій $є$ спілкування іноземними мовами, тобто вміння розуміти усні висловлювання, ініціювати, підтримувати та завершувати бесіди, читати, розуміти, перекладати тексти з урахуванням потреб індивіда.

Проблемам удосконалення професійної іншомовної освіти присвячено низку досліджень таких науковців, як К. Бабенко, І. Бім, Г. Кручініна, Л. Кузнєцова, Р. Мільруд, Н. Мильцева, Є. Михайлова, П. Образцов, О. Поляков, В. Сафонова, О. Сафроненко, С. Сучкова, П. Сисоєв та інші. Водночас аналіз досліджень і публікацій останніх років свідчить, що багато питань, стосовних цієї проблеми, дотепер $\epsilon$ не розв'язаними, серед них: визначення терміна «іншомовна компетентність», її структури, технологій іiї формування в майбутніх фахівців різних галузей тощо. Дискусійними залишаються також питання щодо складників іншомовної компетентності та їх особливостей.

Мета статті - охарактеризувати складники іншомовної компетентності майбутніх інженерів та шляхи їх формування.

Аналіз наукової педагогічної та методичної літератури (Л. Бахман, І. Баценко, М. Вятютнєв, П. Гальперін, І. Зимня, Г. Китайгородська, О. Коваленко, К. Нікітіна, С. Ніколаєва, Д. Шейлз, Л. Шерстюк та інші) показує, що іншомовна компетентність має складну багатокомпонентну структуру, яка грунтується на компетенціях різних рівнів: лінгвістичному, комунікативному, прагматичному, соціокультурному, особистісному.

Так, Ю. Апресян уважає, що «володіти мовою» означає: 1) уміти виражати заданий зміст різними способами; 2) уміти із висловлювання певною мовою здобувати смисл, зокрема розрізнювати зовнішньо подібні, але різні за смислом висловлювання та знаходити загальний смисл у зовнішньо різних висловлюваннях; 3) уміти розрізнювати правильні в мовному відношенні речення від неправильних [1, с. 251]. Це зумовлює необхідність формування іншомовної компетентності - оволодіння нормами іноземної мови. Під нормою розуміється 
сукупність обов'язкових для всіх мовців і загальноприйнятих правил використання мовних одиниць, а також стилістичних ресурсів мовної системи. Тому особливе місце під час вивчення іноземної мови посідає засвоєння ключових, базових понять лінгвістики, з-поміж яких: норма літературної іноземної мови, головні властивості й ознаки літературної мовної норми (ортологічний аспект), стилістичні ресурси мови, мовні ресурси різних стилів і жанрів (стилістичний аспект) тощо. Нормативний аспект володіння іноземною мовою не може існувати окремо від інших аспектів: комунікативного, прагматичного, соціолінгвістичного тощо.

3 точки зору антропологічної парадигми розгляду мови В. Телія визначає п'ятичленне розмежування основних форм репрезентації мовного матеріалу: мова - узус - мовленнєва діяльність - норма - мовлення [6, с. 38]. Кожна 3 цих репрезентацій передбачає існування в структурі мовної особистості особливого виду компетенцій. Відповідність між видами компетенцій і формами презентації мовного матеріалу має такий вигляд:

- мова - мовна компетенція;

- узус - семантична (культурно-мовна) компетенція;

- мовленнсва діяльність - комунікативна компетенція;

- норма - нормативна компетенція;

- мовлення - виконавча компетенція.

Аналізуючи структуру іншомовної компетентності, необхідно враховувати мовну сутність особистості, яка, на думку дослідників (Ю. Караулов, Г. Богін, Л. Крисін, В. Фурманова, I. Халєєва та ін.), є певним інтегративним цілим і має такі рівні організації:

1) лінгвістичний (лексикон особистості);

2) соціолінгвістичний (тезаурус особистості, який відбиває образ світу та систему знань про світ);

3) прагматичний (прагматикон особистості як система цінностей, мотивів, установок й інтенціональності особистості) [4, с. 264].

Згідно з документом Ради Європи «Загальноєвропейські компетенції володіння іноземною мовою: вивчення, викладання, оцінка» [5], у якому описуються стратегії з активізації загальної та комунікативної компетенції задля виконання мовленнєвих дій для розв'язання комунікативних завдань у різних ситуаціях спілкування, іншомовна компетентність як багатокомпонентне явище включає три аспекти: лінгвістичний, соціолінгвістичний, прагматичний. Лінгвістичний аспект охоплює знання фонології, лексики, граматики (морфології та синтаксису) та знання, пов'язані з іншими аспектами мовної системи. Соціолінгвістичний аспект пов'язаний із соціокультурними умовами використання іноземної мови: правила поведінки в суспільстві, норми ввічливості, правила, що регулюють взаємовідносини між різними поколіннями, класами, соціальними групами, а також мовна кодифікація основних норм і ритуалів, прийнятих у суспільстві. Прагматичний аспект визначається функціональним використанням мовних засобів у мовленнєвій діяльності, знаннями принципів, відповідно до яких висловлювання формується та структурується, використовується для виконання комунікативних функцій, будується в певній послідовності за прийнятими в суспільстві моделями взаємодії, а також екстралінгвістичними чинниками (міміка, жести, поза), що забезпечують спілкування.

Л. Бахман [9] підкреслює, що прагматичний аспект пов'язаний із стосунками між людьми, які використовують мову, та конкретним контекстом спілкування, складається з ілокутивної та соціолінгвістичної компетенцій. Ілокутивна компетенція - це знання прагматичних умовностей виконання потрібних функцій мови, здатність цих функцій формувати ілокутивні (мовленнєві) акти (інформувати, запросити, прохати тощо) відповідно до ситуації спілкування. Соціолінгвістична компетенція - знання відповідних соціокультурних умовностей застосування функцій мови в заданому контексті.

Соціолінгвістичний аспект у структурі іншомовної компетентності визначає також І. Бім, характеризуючи іiі як «володіння мовними засобами, процесом породження мовлення й розпізнавання тексту» $[3$, с. 10$]$.

Комунікативний аспект у науковій педагогічній і методичній літературі розуміється як найбільш оптимальне, доцільне використання мовних засобів відповідно до висунутих комунікативних цілей i завдань у різних ситуаціях усного та писемного спілкування. Комунікативний аспект володіння мовою передбачає розвиток комунікативних здібностей 
особистості, тобто вміння ефективно взаємодіяти 3 партнером спілкування 3 урахуванням прагматичних параметрів комунікації.

О. Тихомирова характеризує комунікативний компонент у структурі іншомовної компетентності як здатність будувати правильні, відповідно до норм мови, що вивчається, власні висловлювання та сприймати чужі, підкреслюючи, що він виявляється у правильному використанні лінгвістичних форм (фонологія, морфологія, лексика, синтаксис) іноземною мовою [7, с. 130].

Ф. Бацевич визначає комунікативну компетенцію як «сукупність знань і умінь учасників інтеракції спілкування у різноманітних умовах (ситуаціях) з різними комунікантами; набір комунікативних стратегій разом із володінням комунікативними правилами, максимами, постулатами і конвенціями спілкування» [2, с. 328].

Відомо, що мова виконує роль головного засобу спілкування відповідно до певних зовнішніх умов, до яких відносяться, зокрема, соціальне завдання мовленнєвого спілкування (функція повідомлення інформації, функція впливу, функція оцінювання інформації), ситуації мовленнєвої дії (офіційна, неофіційна), характер комунікації (усна або писемна маніфестація мови). Тому формування комунікативної компетенції майбутнього інженера означає не лише оволодіння необхідним набором мовознавчих і мовленнєвознавчих знань, формування вмінь практичного використання мови в процесі мовленнєвої діяльності, але й реалізація виховних завдань щодо формування соціально активної, професійно підготовленої особистості, яка орієнтується в сучасному світі. Комунікативна компетенція стає необхідною частиною загальнокультурної компетенції, що передбачає підвищення загальної гуманітарної культури особистості, формування в неї високих творчих, світоглядних і поведінкових якостей, необхідних для іiі залучення до різноманітних видів діяльності, а саме: знання етичних, моральних норм, норм і правил мовленнєвого етикету та мовленнєвої поведінки, соціокультурних норм і стереотипів мовленнєвого спілкування.

У науковій літературі (В. Аітов, Л. Акопян, Г. Борозинець, Л. Гейхман, Л. Заблоцька, І. Нужа, Ю. Солоднікова та ін.) підкреслюється, що головним компонентом комунікативної компетенції є мовленнєві вміння, що формуються на грунті мовних знань і навичок i лінгвокраїнознавчих знаннях. У процесі спілкування наявна орієнтація на соціальні характеристики мовленнєвого партнера: його статус, позицію, ситуаційну роль тощо.

Мета формування комунікативної компетенції - комунікативний акт, засоби - ії складники (мовленнєві вміння, мовні знання та навички, лінгвокраїнознавчі знання). Дослідники (наприклад, Р. Осадчук, С. Трубачова [8] та ін.) визначають етапи та мету формування комунікативної компетенції в студентів. Так, на першому, підготовчому, етапі студенти ознайомлюються з різними структурно-семантичними типами комунікативної єдності та ії складниками; мета - формувати в студентів комунікативні навички та розвивати вміння спілкуватися на початковому рівні. Студенти повинні оволодіти набором комунікативних дій, які надають змогу брати участь у навчальній комунікації в обсязі комунікативної єдності, побудованої на вивченні лексико-граматичного матеріалу, створювати діалоги з 2-3 реплік за аналогією, відпрацьовуються вміння та навички правильного оформлення різних за типом реплік (репліки-реакції та репліки-стимули).

На другому етапі студенти вдосконалюють знання, вміння та навички розкриття комунікації, складають діалоги на основі текстів; мета - розвиток комунікативної компетенції середнього рівня. Цей етап передбачає оволодіння набором комунікативних дій, які надають студентам змогу брати участь у мікрокомунікації, зростає обсяг їхньої комунікативної поведінки: 1) збільшення кількості реплік завдяки поєднанню реакції та стимулу або через уведення в них монологічного мовлення; 2) розширення комунікативної єдності; 3) самостійність через зменшення участі викладача в студентських комунікаціях, скорочення контролю, більш спрямованого на вибір мовних засобів і змісту реплік. Студенти вчаться складати діалоги, використовуючи необхідні тексти, відповідно до запропонованої ситуації емоційно реагувати на почуте.

На третьому етапі активізується комунікативна діяльність студентів; мета - розвиток комунікативних знань, умінь і навичок студентів на більш високому рівні, що передбачає здатність до участі в розширеній комунікації, у навчальній ситуації. Таке спілкування імітується за допомогою вивчення набору комунікативних дій та операцій, тематичного 
мінімуму. Студенти самостійно обирають конкретні цілі, визначають предмет спілкування; через вибір комунікативної дії діалогічне мовлення поєднує мовлення як засіб та мету навчання. Студенти повинні оволодіти такими знаннями, вміннями та навичками, як: розуміти на слух мовлення викладача та студентів, виявляти помилки в розмові, розуміти головну думку розмови, самостійно добирати назву до теми розмови тощо. На етапі активізації комунікативної компетенції студентів на практиці передбачаються такі види навчальної роботи, як: бесіда, дискусія, дидактична гра; студенти навчаються коментувати запропонований текст у створеній ситуації, продовжувати розпочате спілкування тощо. Кінцева мета цього етапу - достатньо вільне володіння непідготовленою розмовою 3 використанням структурно-семантичних типів комунікативної єдності.

Значення в розвитку іншомовного мовлення під час комунікації набуває спеціально розроблений дидактичний матеріал, який сприяє розв'язанню навчальних і виховних завдань.

У процесі навчання іноземної мови необхідно формувати такі компоненти комунікативної компетенції студентів, як: уміння та навички орієнтуватися в ситуації (визначати власну мету спілкування; створювати уявлення про спілкування; прогнозувати його загальний характер згідно 3 темою); вміння та навички розуміти зміст ситуації (сприймати загальний зміст спілкування, запам'ятовувати зміст спілкування, формулювати тему й головну думку; добирати назву відповідно до теми й головної думки почутого; осмислювати деталі почутого повідомлення; аналізувати зміст спілкування з теми; відповідати на питання з теми спілкування); вміння та навички визначати структуру ситуації спілкування (осмислювати та фіксувати загальну структуру спілкування; виділяти логіко-смислові частини спілкування; встановлювати логічний зв'язок 3 елементами розмови, відтворювати їх на слух; визначати побудову спілкування; ставити питання до смислових частин розмови); вміння та навички оцінювати ситуацію спілкування (перевіряти результати сприйняття поставленої мети; робити висновки з проблеми ситуації спілкування; висловлювати власну думку з приводу спілкування, аргументувати власну позицію).

Задля розвитку комунікативної компетенції студентів на заняттях з іноземної мови доцільно застосовувати такі види роботи, як: прослуховування ситуації спілкування, сприйняття та запам'ятовування, коментування висловлювання, його доповнювання реплікою-стимулом, виокремлення нової інформації про події, явища; завершення розмови на підгрунті почутого раніше, самостійне завершення розмови, визначення можливого змісту розмови за ії темою, виявлення в розмові несумісних за смислом реплік тощо. За допомогою різноманітних оперативних і комунікативних завдань формуються вміння та навички побудови діалогічних реплік і діалогу загалом.

Отже, навчання іноземної мови студентів-майбутніх металургів передбачає реалізацію навчальних, виховних і розвивальних завдань; практична мета - розвиток їхньої мовленнєвої активності в іншомовному спілкуванні.

3 огляду на специфіку іншомовної підготовки в технічному ВН3, іншомовна компетентність як невід'ємний складник професійної компетентності майбутнього інженера $€$ сукупністю лінгвістичних, комунікативних, соціокультурних, прагматичних знань і суб'єктноособистісного досвіду фахівця в їх використанні, яка дозволяє послуговуватися іноземною мовою в професійній, науковій, дослідницькій діяльності та задля самоосвіти, ефективно здійснювати міжкультурну професійну взаємодію.

\section{Література}

1. Апресян Ю. Д. Лексическая семантика. Синонимические средства языка / Ю. Д. Апресян. - М. : Наука, 1974. - 368 с. 2. Бацевич Ф. С. Основи комунікативної лінгвістики: [підручник] / Флорій Сергійович Бацевич. - К. : Вид. центр «Академія», 2004. - 344 с. - (Альма-матер). 3. Бим И. Л. Немецкий язык. Базовый курс. Концепция, программа / И. Л. Бим. - М. : Новая школа, 1995. - 59 с. 4. Караулов Ю. Н. Русский язык и языковая личность / Ю. Н. Караулов. - М. : Наука, 1987. - 264 с. 5. Общеевропейские компетенции владения иностранными языками: изучение, преподавание, оценка / [под ред. К. М. Ирисхановой]. - М. : Изд-во МГЛУ, 2003. - 256 с. 6. Телия В. Н. Механизмы экспрессивной окраски языковых единиц / В. Н. Телия // Человеческий фактор и язык: Языковые механизмы экспрессивности. - М., 1991. - С. 36-66. 7. Тихомирова Е. В. Контроль владения диалогической формой устного официального общения (франц. яз., неяз. вуз): дис. ... канд. пед. наук: 13.00 .08 / Е. В. Тихомирова. - М., 1995. - 178 с. 8. Трубачева С. К вопросу о развитии коммуникативной компетенции учеников основной школы / С. Трубачева, Р. Осадчук // Образование управления. - 2005. - № 2. - C. 95-99. 9. Bachman L. F. Fundamental Considerations in Language Testing / L. F. Bachman. - Oxford: Oxford University Press, 1990. - 408 p. 